\title{
Briefing: Lessons learned from failures of flood defences
}

1 Sebastiaan N. Jonkman

Professor of Hydraulic Engineering, Delft University of Technology, Faculty of Civil Engineering and Geosciences, Department of Hydraulic Engineering, Delft, the Netherlands
2 Timo Schweckendiek

Lecturer, Delft University of Technology, Faculty of Civil Engineering and Geosciences, Department of Hydraulic Engineering, Delft, the Netherlands; also Deltares, Delft, the Netherlands
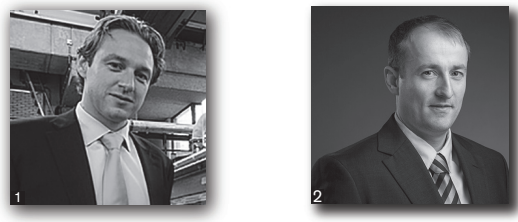

Failure of flood defences during extreme events can lead to enormous damage and loss of life. This paper presents lessons learned from investigations of flood events over recent years, including the $\mathbf{2 0 0 5}$ flooding in New Orleans, USA, caused by hurricane Katrina. Based on these findings, new developments in the field of research, design and engineering of flood defences are discussed, such as the introduction of risk-based approaches and better utilisation of failure data, field observations and monitoring. Such approaches are crucial to allow extrapolation for more extreme load conditions due to climate change, with anticipated sea level rise and increasing precipitation.

\section{Introduction}

The majority of the global population is located in flood-prone coastal deltas, coastal areas and along rivers. Failure of flood defences (also termed levees, dykes or embankments) during extreme events can lead to enormous damage and loss of life (e.g. Jonkman, 2005). Therefore, an adequate understanding of the safety and vulnerability of flood defences is essential for design and assessment purposes. In this paper a few of the lessons learned from investigations of recent flood events are highlighted. Based on these findings, new developments are discussed, such as the introduction of risk-based design approaches and better utilisation of failure data, field observations and monitoring.

\section{Lessons from historical failures of flood defences}

In order to illustrate some lessons learned from large-scale flood events in the last decade, the authors have synthesised a number of general observations and lessons learned. Table 1 provides an overview of the considered events, some of which the authors have been involved with through postflood field investigations. Note that this is just a very small sample of the total number of significant flood events in this period of time.
Although all events are characterised by unique conditions and patterns, a number of general observations can be derived from the post-flood investigation reports.

\subsection{The importance of geotechnical failures}

During the flood events along the Elbe, the dyke failure in Wilnis and the flooding of the central parts of New Orleans, geotechnical failure mechanisms such as instability and internal erosion (piping) were the main causes of flooding (see Figure 1 for an example of a geotechnical failure). These mechanisms occur while the outside water level is below the crest or top of the flood defence structure. Uncertainty in ground conditions and the presence of unidentified adverse geological details are common causes of failures (Danka and Zhang 2015). This highlights the need for proper site investigation and the use of all the information that can be obtained on the (sub)soil conditions.

\subsection{Vulnerability of transitions}

In Thailand and New Orleans the transitions between hard structures and earthen dykes proved to be vulnerable weak links. In many cases erosion started at these locations. Design and safety assessment of flood defences often focuses on representative cross-sections, for which appropriate computational models are available. It seems that engineers are doing 
Forensic Engineering

Volume 168 Issue FE2
Briefing: Lessons learned from

failures of flood defences

Jonkman and Schweckendiek

\begin{tabular}{|c|c|c|c|c|}
\hline Event and location & Date/period & $\begin{array}{l}\text { Type of } \\
\text { event }\end{array}$ & Main failures and failure mechanisms & References \\
\hline Wilnis, Netherlands & $\begin{array}{l}26 \text { August } \\
2003\end{array}$ & Drought & $\begin{array}{l}\text { Single canal dyke failure due to horizontal sliding. } \\
\text { Peat dyke had decreased in weight significantly } \\
\text { owing to a long drought period }\end{array}$ & Van Baars (2005) \\
\hline $\begin{array}{l}\text { Hurricane Katrina, } \\
\text { New Orleans (2005) }\end{array}$ & $\begin{array}{l}29 \text { August } \\
2005\end{array}$ & $\begin{array}{l}\text { Hurricane } \\
\text { surge }\end{array}$ & $\begin{array}{l}\text { About } 25 \text { breaches; in the eastern part of the city } \\
\text { these were due to overflow and overtopping, in the } \\
\text { central part due to sliding and piping }\end{array}$ & $\begin{array}{l}\text { IPET (2008), Seed } \\
\text { et al. (2008a, 2008b }\end{array}$ \\
\hline $\begin{array}{l}\text { Storm Xynthia, Girone } \\
\text { and Loir estuaries, France } \\
\text { Chao Phraya river basin, }\end{array}$ & $\begin{array}{l}28 \text { February } \\
2010\end{array}$ & Storm surge & $\begin{array}{l}\text { Overflow and failure of dykes and dunes owing to } \\
\text { erosion at several places }\end{array}$ & Kolen et al. (2013) \\
\hline Thailand & $\begin{array}{l}\text { October- } \\
\text { November } \\
2011\end{array}$ & $\begin{array}{l}\text { Large-scale } \\
\text { river floods }\end{array}$ & $\begin{array}{l}\text { More than ten failures owing to overflow of the } \\
\text { system }\end{array}$ & ENW (2012) \\
\hline $\begin{array}{l}\text { Elbe floods (in 2013), } \\
\text { Germany }\end{array}$ & June 2013 & River floods & $\begin{array}{l}\text { 50-500-year return period event. Several dyke } \\
\text { failures due to geotechnical failure mechanisms }\end{array}$ & ENW (2013) \\
\hline
\end{tabular}

a sound job on these standard profiles, but the transitions between them are often engineered unsatisfactorily.

\subsection{Multiple breaches}

The floods in New Orleans (in 2005), Thailand (in 2011) and Germany (in 2013) were characterised by a large number of breaches in the flood protection system. However, other historical events, such as the 1953 storm surge in the Netherlands (more than 100 failures) or the Elbe floods (in Germany, during 2002) with more than 70 failures (Heyer and Horlacher, 2007), show similar patterns. In all these cases

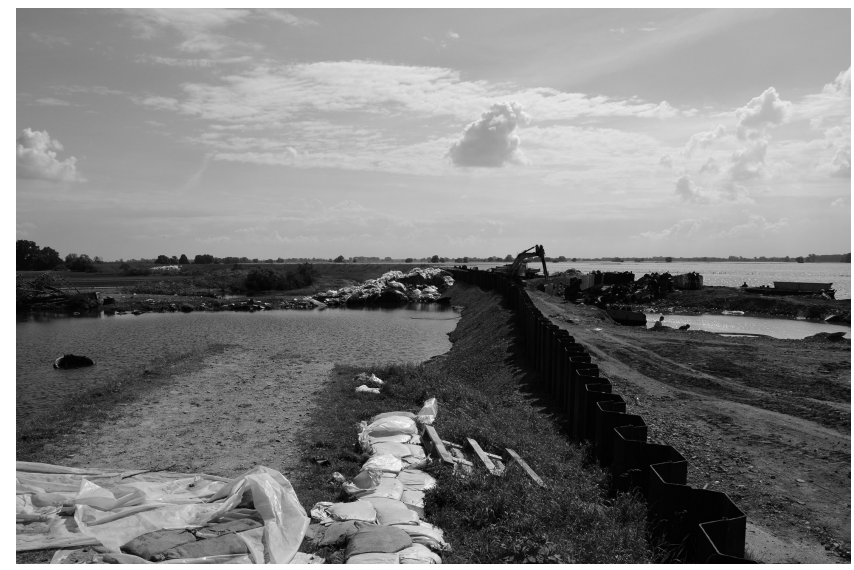

Figure 1. Breach of about $100 \mathrm{~m}$ width at Fischbeck along the Elbe (Germany, June 2013) induced by a geotechnical failure. The photograph shows the breach with the emergency repair works, consisting of a sheet pile in a soil embankment overloading of the system led to multiple failures, exacerbating the extent of the flooding and the damage.

\subsection{Human and organisational factors}

Evaluations after the floods highlighted that the flood defence systems were not properly designed for the events they faced. The canal dykes in Thailand were mainly built for water management purposes, but not for that level of flooding. The pre-Katrina hurricane protection system of New Orleans was 'a system in name only' (IPET, 2008), as it had varying elevations and insufficient strength for resistance against geotechnical failures. Also, there were striking differences in elevations of levee sections exposed to similar hydraulic conditions (i.e. water levels). Human and organisational factors, as well as poor management and maintenance, played a key role in the New Orleans failures (Bea, 2008) as well as in many other cases worldwide.

\subsection{Damage and loss of life}

The last general lesson concerns the large damages caused by failures of flood defences. The failures of flood defences of New Orleans caused hundreds of fatalities and billions of US dollars' worth of damage. The economy of Thailand was disrupted for several months owing to the flooding, and the flood caused a significant drop in economic growth. Almost 50 people were killed - a lot of them trapped in vacation homes during the coastal floods in France (Lumbroso and Vinet, 2011). During the events in France and New Orleans, elderly people appeared to be most vulnerable. The (material and immaterial) costs of large-scale flooding are many times higher when compared to the costs of building and maintaining proper protection. 


\section{New developments and directions}

Based on these observations and lessons, a number of challenges and new promising developments are addressed in the field of research and design of flood defences, which should contribute to better understanding, improved performance and higher reliability.

\subsection{Probabilistic design and risk analysis}

Flood defence failures teach us that some failure modes are usually more critical in design than others, among other aspects, this can be attributed to the uncertainties faced in different conditions (e.g. loads or ground conditions). Probabilistic design allows the provision of tailor-made solutions, by taking all failure modes and all elements of the protection system into account, as well as their dependence in terms of reliability. This in turn allows targeted and costeffective investment at weak spots. The Dutch VNK2 project (Jongejan and Maaskant, 2015) is a recent example of a rigorous nationwide flood risk analysis. It has led to major insights in, for example, the relative importance of failure modes, such as backward erosion piping or geotechnical stability. Furthermore, the insights of this project have been heavily relied on in the decisions on new safety standards for flood defences in the Netherlands (Delta Program, 2014). These standards are formulated in terms of acceptable probabilities of flooding, which have been derived from assessments of both economic risk and risk to life. Also, in other countries, the use of risk-based protection standards is investigated. For example, in the USA, the National Research Council has recommended the use of risk assessment to derive standards for coastal flood protection (NRC, 2014).

\subsection{Learning from actual failures}

Despite extensive theoretical and experimental research on failure modes of flood defences such as instability, internal erosion or overflow-induced breaching, considerable uncertainties in failure modelling and prediction remain. The understanding of geotechnical failure mechanisms can be significantly improved by hind-casting historical levee failures (see e.g. Kanning et al., 2008; Rajabalinejad et al., 2010). The learning aspects are essentially three-fold.

The models can be improved by better calibration.

It is possible to learn which failure modes or types of structures are the most critical, and in which conditions.

- 'New' failure modes are discovered that are not yet commonly considered in designs.

One example of the latter is the canal dyke at Wilnis, which failed in 2002 owing to a combination of circumstances hitherto unknown to practitioners. The peat in the dyke body had dried out, leading to a considerable decrease in its weight, plus drying cracks in the subsoil led to changes in the water pressures under the levee. In the aftermath, this failure mode was incorporated in the relevant Dutch guidelines.

Furthermore, individual efforts have been undertaken to document failures of flood defences after disasters (e.g. Heyer and Horlacher, 2007; Seed et al., 2008a, 2008b), yet no systematically gathered large-scale datasets are available for thorough scientific research in the way that they exist for other civil engineering domains (Breysse, 2012). Recently, the present authors launched an initiative to set up an international levee performance database, in order systematically to collect and analyse levee performance data; this should allow the research community to improve understanding of the performance of flood defences, on a systems level as well as for individual structures and failure modes.

\subsection{Learning from observations}

Near-failures or performance observations at heavily loaded flood defences can provide valuable information for safety assessments and reinforcement designs. Schweckendiek et al. (2014) demonstrate how observations of good performance (e.g. survival or no damage), as well as of bad performance (e.g. seepage or sand boils) without failure can significantly change the probability of backward internal erosion failure for future events, by reducing the uncertainty in geotechnical conditions. Monitoring the pore pressure response to external loading by increased water levels provides similar insights (Schweckendiek et al., 2013).

As geotechnical uncertainties play a key role, better site characterisation is needed. Probabilistic and risk-based approaches can also help to optimise investments by balancing the investigation cost with the risk reduction achieved, or by minimising the cost to achieve a pre-defined reliability target.

\section{Conclusion}

Given the large economic damage potential in most flood-prone areas, the available means to reduce uncertainty should be employed to reduce flood risk and to target investments in flood protection at the most effective spots.

A better understanding and more robust design of flood defences systems will become even more important in the future, when hydraulic loads are expected to increase due to the effects of sea-level rise and increasing precipitation. This will lead to more frequent events that are beyond the domain of our experience with the defences' performance. Proper understanding of flood defence failure then becomes crucial in extrapolating to more extreme load conditions.

Information from actual failures is particularly valuable. Important lessons have been learned from them in the past and this line of work must be continued. Preferably, this should 
be done in a more systematic manner, such that the insights are shared more effectively among researchers and with practitioners. Also near-misses and performance observations from non-failed flood defences contribute to overall understanding.

Moreover, the demand for safety will increase, owing to the economic and population growth in urbanised flood-prone regions (Hallegatte et al., 2013). A better understanding of the reliability and failure mechanisms of flood defences will contribute to safer and more cost-effective designs, and ultimately to reducing damages and loss of life.

\section{REFERENCES}

Bea RG (2008) Failure of the New Orleans 17th Street Canal levee and floodwall during hurricane Katrina. In Proceedings of Geocongress 2008, New Orleans, LA, USA, pp. 1-20. See http://www.urbanflood.eu/Documents/ Failure $\% 20$ of $\% 20$ the $\% 20$ New $\% 20$ Orleans $\% 2017$ th $\%$ 20 street $\% 20$ canal $\% 20$ levee $\% 20$ and $\% 20$ floodwall.pdf (accessed 16/01/2015).

Breysse D (2012) Forensic engineering and collapse databases. Proceedings of the Institution of Civil Engineers - Forensic Engineering 165(2): 63-75, http://dx.doi.org/10.1680/feng. 10.00001

Danka J and Zhang L (2015) Dike failure mechanisms and breaching parameters. Journal of Geotechnical and Geoenvironmental Enginerring, http://dx.doi.org/10.1061/ (ASCE)GT.1943-5606.0001335.

Delta Program (2014) Working on the Delta - Decisions to Keep the Netherlands Safe and Liveable. Delta Programme Commissioner, The Hague, the Netherlands, report. See http://deltacommissaris.nl/english/ delta-programme/delta-programme-2015/ (accessed 01/02/ 2015).

ENW (Expertise Network on Flood Protection) (2012) Post-flood field investigation in the Lower Chao Phraya River Basin, 23-27 January 2012, Preliminary findings of the ThaiDutch Reconnaisance Team, Final report.

ENW (2013) Floods in Germany (June 2013), Post-flood field investigation, Preliminary findings.

Hallegatte S, Green C, Nicholls RJ and Corfee-Morlot J (2013) Future flood losses in major coastal cities. Nature Climate Change 3: 816-821, http://dx.doi.org/doi:10.10238/ nclimate1979

Heyer T and Horlacher HB (2007) Analyse der Deichbrüche an Elbe und Mulde während des Hochwassers 2002 im Bereich Sachsens. Proceedings of the DWA Seminar, Fulda, Germany (in German).

IPET (Interagency Performance Evaluation Task Force) (2008) Final Report of the Interagency Performance Evaluation Task Force (IPET) Volume I-Executive Summary and Overview, June 1, 2008.
Jongejan RB and Maaskant B (2015) Quantifying flood risks in the Netherlands. Risk Analysis 35(2): 252-264, http://dx.doi. org/doi/10.1111/risa.12285

Jonkman SN (2005) Global perspectives of loss of human life caused by floods. Natural Hazards 34(2): 151-175.

Kanning W, van Baars S, Vrijling JK (2008) The stability of flood defenses on permeable soil: the London avenue canal failures in New Orleans. In Proceedings of the 6th International Conference Case Histories in Geotechnical Engineering. (Prakash S (ed.)). Missouri University of Science and Technology, Rolla, MI, USA.

Kolen B, Slomp R and Jonkman SN (2013) The impacts of Storm Xynthia Feb. 27-28, 2010 in France: first lessons for flood risk management. Journal of Flood Risk Management 6(3): 261-278.

Lumbroso DM and Vinet F (2011) A comparison of the causes, effects and aftermaths of the coastal flooding of England in 1953 and France in 2010. Natural Hazards and Earth System Sciences 11: 2321-2333, http://dx.doi.org/10.5194/nhess-112321-2011

NRC (National Research Council) (2014) Reducing Coastal Risk on the East and Gulf Coasts. The National Academies Press, Dulles, VA, USA, Report by the Committee on U.S. Army Corps of Engineers Water Resources Science, Engineering, and Planning: Coastal Risk Reduction.

Rajabalinejad M, PHAJM van Gelder, Demirbilek Z, Mahdi T-F and Vrijling JK (2010) Application of the dynamic bounds method in the safety assessment of flood defences, a case study: 17th Street flood wall, New Orleans. Georisk 45(4): 157-173.

Schweckendiek T and Vrouwenvelder ACWM (2013) Reliability updating and decision analysis for head monitoring of levees. Georisk 7(2): 110-121.

Schweckendiek T, Vrouwenvelder ACWM, Calle EOF et al. (2013) Partial factors for flood defenses in the Netherlands. In Modern Geotechnical Codes of Practice - Development and Calibration (Arnold P, Fenton GA, Hicks MA et al. (eds)). IOS Press, Amsterdam, Special Geotechnical Publication.

Schweckendiek T, Vrouwenvelder ACWM and Calle EOF (2014) Updating piping reliability with field performance observations. Structural Safety 47: 13-23, http://dx.doi.org/ 10.1016/j.strusafe.2013.10.002.

Seed R, Bea R, Athanasopoulos-Zekkos A et al. (2008a) New Orleans and Hurricane Katrina. III: The 17th Street Drainage Canal. Journal of Geotechnical and Geoenvironmental Engineering 134(5): 740-761.

Seed R, Bea R, Athanasopoulos-Zekkos A et al. (2008b) New Orleans and Hurricane Katrina. II: The Central Region and the Lower Ninth Ward. Journal of Geotechnical and Geoenvironmental Engineering 134(5): 718-739.

Van Baars S (2005) The horizontal failure mechanism of the Wilnis peat dike. Géotechnique 55(4): 319-323. http://dx.doi. org/10.1680/geot.2005.55.4.319 